\title{
Seasonal Variation in Soil Greenhouse Gas Emissions at Three Age-Stages of Dawn Redwood (Metasequoia glyptostroboides) Stands in an Alluvial Island, Eastern China
}

\author{
Shan Yin ${ }^{1,2,3,+}$, Xianxian Zhang ${ }^{1,2,3,+}$, Jukka Pumpanen ${ }^{4}$, Guangrong Shen ${ }^{1,3}$, Feng Xiong ${ }^{1}$ and \\ Chunjiang Liu $1,2,3, *$ \\ 1 School of Agriculture and Biology, Research Centre for Low Carbon Agriculture, Shanghai Jiao Tong \\ University, 800 Dongchuan Rd., Shanghai 200240, China; yinshan@sjtu.edu.cn (S.Y.); \\ xixizi01090@163.com (X.Z.); sgrong@sjtu.edu.cn (G.S.); xiongfeng478@163.com (F.X.) \\ 2 Shanghai Urban Forest Ecosystem Research Station, State Forestry Administration, 800 Dongchuan Rd., \\ Shanghai 200240, China \\ 3 Key Laboratory for Urban Agriculture (South), Ministry of Agriculture, 800 Dongchuan Rd., \\ Shanghai 200240, China \\ 4 Department of Environmental and Biological Sciences, University of Eastern Finland, P.O. Box 1627, Kuopio \\ 70211, Finland; jukka.pumpanen@uef.fi \\ * Correspondence: chjliu@sjtu.edu.cn; Tel./Fax: +86-21-3420-6603 \\ + These authors contributed equally to this work.
}

Academic Editors: Robert Jandl and Mirco Rodeghiero

Received: 26 August 2016; Accepted: 21 October 2016; Published: 4 November 2016

\begin{abstract}
Greenhouse gas (GHG) emissions are an important part of the carbon (C) and nitrogen $(\mathrm{N})$ cycle in forest soil. However, soil greenhouse gas emissions in dawn redwood (Metasequoia glyptostroboides) stands of different ages are poorly understood. To elucidate the effect of plantation age and environmental factors on soil GHG emissions, we used static chamber/gas chromatography (GC) system to measure soil GHG emissions in an alluvial island in eastern China for two consecutive years. The soil was a source of $\mathrm{CO}_{2}$ and $\mathrm{N}_{2} \mathrm{O}$ and a sink of $\mathrm{CH}_{4}$ with annual emissions of 5.5-7.1 Mg C ha ${ }^{-1}$ year $^{-1}, 0.15-0.36 \mathrm{~kg} \mathrm{~N}^{-1}$ year $^{-1}$, and $1.7-4.5 \mathrm{~kg} \mathrm{C} \mathrm{ha}^{-1}$ year $^{-1}$, respectively. A clear exponential correlation was found between soil temperature and $\mathrm{CO}_{2}$ emission, but a negative linear correlation was found between soil water content and $\mathrm{CO}_{2}$ emission. Soil temperature had a significantly positive effect on $\mathrm{CH}_{4}$ uptake and $\mathrm{N}_{2} \mathrm{O}$ emission, whereas no significant correlation was found between $\mathrm{CH}_{4}$ uptake and soil water content, and $\mathrm{N}_{2} \mathrm{O}$ emission and soil water content. These results implied that older forest stands might cause more GHG emissions from the soil into the atmosphere because of higher litter/root biomass and soil carbon/nitrogen content compared with younger stands.
\end{abstract}

Keywords: greenhouse gas; seasonal variation; subtropical; soil temperature; soil moisture

\section{Introduction}

Establishment and management of forest plantations play an increasingly important role in sequestrating carbon from the atmosphere as one of the major strategies for mitigating global warming. The emissions of greenhouse gases (GHGs) are mostly related to the carbon (C) and nitrogen (N) cycle from forest soils. Forest soils are the sink of carbon in the world and contain about $704 \mathrm{Pg} \mathrm{C}$, with varying $C$ densities under different environmental conditions [1]. On the contrary, they are also the source of $\mathrm{N}_{2} \mathrm{O}[1,2]$. In some countries (e.g., China, India, Russian Fedration, US, Japan, etc.), plantations represent an important part of the national forested areas, and are increasing at the 
rate of 3-4.5 million hectare per year [3]. China accounts for $24 \%$ of the global forest plantations [3]. In China, the plantation area increased by 5.1 million ha per year during the period from 2004-2008 [4]; it is expected that 40 million hectares plantation will be established within the period from 2005 to 2020 [5]. To further our understanding of the patterns of $\mathrm{C}$ and $\mathrm{N}$ cycles and influential factors, we need to study the soil GHG emissions and their ability to mitigate global warming.

A large number of studies have been conducted about tropical forest soil GHG emissions. For instance, soil $\mathrm{CO}_{2}$ emissions ranged from $1.45 \mathrm{t} \mathrm{C} \mathrm{ha}^{-1}$ year $^{-1}$ to $13.74 \mathrm{t} \mathrm{C}^{-1}$ year $^{-1}$ in subtropical forests of China [6-8], to $10.80 \mathrm{tC} \mathrm{ha}^{-1}$ year $^{-1}$ to $11.75 \mathrm{t} \mathrm{C} \mathrm{ha}^{-1}$ year $^{-1}$ in subtropical Australian rainforests [9], and $25.60 \mathrm{tC} \mathrm{ha}^{-1}$ year $^{-1}$ in tropical Thailand forests [10]. Average soil $\mathrm{N}_{2} \mathrm{O}$ emissions varied from $1.5 \mathrm{~kg} \mathrm{~N} \mathrm{ha}^{-1}$ year $^{-1}$ to $6.07 \mathrm{~kg} \mathrm{~N}^{-1}$ year ${ }^{-1}$ in tropical forests [11-13]. Mean annual $\mathrm{CH}_{4}$ uptake in tropical forest ecosystems ranged from $3.33 \mathrm{~kg} \mathrm{C}^{-1}$ year ${ }^{-1}$ to $57.49 \mathrm{~kg} \mathrm{C} \mathrm{ha}^{-1}$ year ${ }^{-1}$ [14,15], and net $\mathrm{CH}_{4}$ sinks in tropical Montane tree forests ranged from $0.6 \mathrm{~kg} \mathrm{C} \mathrm{ha}^{-1}$ year ${ }^{-1}$ to $5.9 \mathrm{~kg} \mathrm{C} \mathrm{ha}^{-1}$ year $^{-1}$ in southern Ecuador [16]. These results show that there are drastic variations in GHG emissions in specific sites across different regional biomes, thereby suggesting that the pattern of GHG emissions and influential factors will need to be elucidated at specific sites in the context of considering the management of plantations as a strategy of sequestrating atmospheric $\mathrm{CO}_{2}$.

The dynamics of soil GHG emissions in forests are influenced by key factors such as soil properties, soil temperature, soil moisture, and vegetation $[15,17,18]$. In previous reports, seasonal changes in soil GHG emissions were found $[19,20]$. Soil $\mathrm{CO}_{2}$ and $\mathrm{N}_{2} \mathrm{O}$ emissions both displayed an increasing trend with the progression of succession in natural forests, but no difference in $\mathrm{CH}_{4}$ emission was observed at different succession stages [2,12]. Few reports had examined GHG emissions at differently aged stages of plantations. Dawn redwood (Metasequoia glyptostroboides), as a living fossil tree, is widely distributed as plantations throughout the middle and high latitudes in Eurasian and North American continents [21]. It had high natural durability under the attack of basidomycetes infection and high resistance against soft-rot fungi [22-24]. As a fast-growing species, Dawn redwood plays an important role in carbon stocks and other ecosystem services. To further understand the pattern of GHG emissions in different aged plantations and associated influential factors, soil GHG emissions were measured at 10, 1, 7 and 32 year old dawn redwood stands for two consecutive years in this study.

These are the following objectives of this study: (1) reveal the seasonal variation of soil GHG emissions at different age-stages of plantations; (2) show the relationship between the GHG emissions and soil temperature, and GHG emissions and moisture; (3) determine the relative importance of biomass, soil C and N content, soil temperature, and soil moisture on GHG emissions; and (4) understand the role of dawn redwood stand soil as the source or sink for $\mathrm{CO}_{2}, \mathrm{CH}_{4}$, and $\mathrm{N}_{2} \mathrm{O}$ at different age stages. We hypothesized that different patterns of GHG emissions could exist in differently aged forests. This is partially due to consideration of the different assimilated products of photosynthesis, some of which are allocated into the roots within a short time period after photosynthesis, for example. As such, GHG emissions are not only affected by soil temperature but are also affected by plant photosynthesis via below-ground carbon allocation.

\section{Materials and Methods}

\subsection{Site Description}

The experimental stands are located in Dongping National Forest Park $\left(41.68^{\circ} \mathrm{N}, 121.48^{\circ} \mathrm{E}\right)$, Chongming Island, Shanghai, China. Chongming Island, the largest alluvial island in the world, is located in the Yangtze River Estuary, which covers an area of $1267 \mathrm{~km}^{2}$ and which currently increases at the rate of 500 ha year ${ }^{-1}$ through Yangtze River-derived sediment [25]. During the period of 2009-2013, the mean annual temperature and precipitation of this area was $16.6^{\circ} \mathrm{C}$ and $1072.3 \mathrm{~mm}$, respectively [26]. Rainfall is concentrated mostly on May-September (Figure 1). 


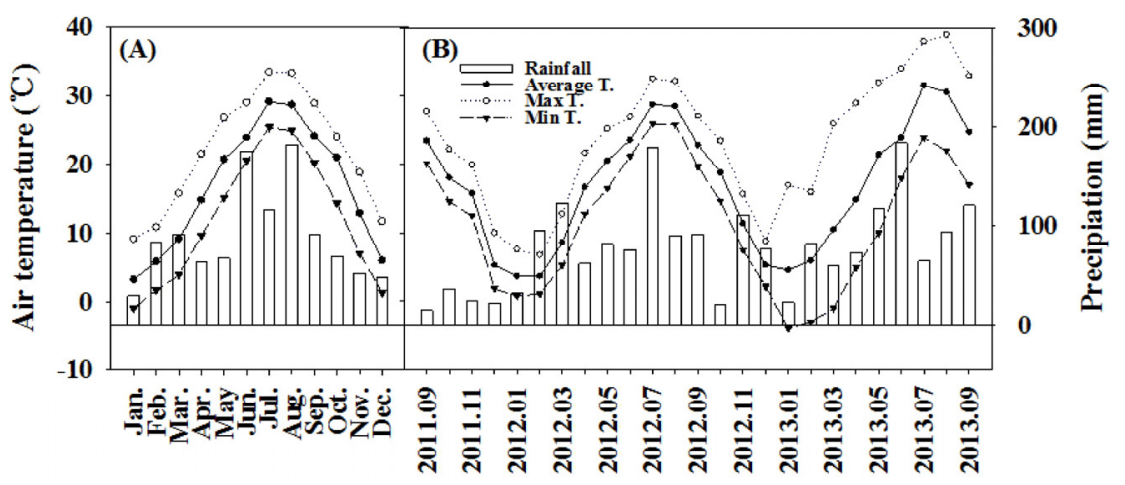

Figure 1. Monthly mean air temperature and precipitation during 2009-2013 (A); the monthly mean temperature and precipitation from September 2011 to September 2013 (B).

Dongping National Forest Park is the largest forest farm in eastern China, with $70 \%$ of the total area covered by dawn redwood plantations. Since the 1960s, plantations have been established to form different aged stands. In order to examine the effects of stand age on soil GHG emission, three different aged stands of 10, 17, and 32 years old were selected. In each stand, three plots $(20 \mathrm{~m} \times 20 \mathrm{~m})$ were set up in August 2011 (Table 1).

Biomass carbon storage. In 2011, all trees were counted at all sites. The height of every single tree was determined by using a Haglöf Vertex III Ultrasonic Hypsometer. The diameter at breast height (1.3 $\mathrm{m}$ above the ground) (DBH) was measured using a measuring tape. The whole tree dry biomass was calculated by Becuwe's allometric functions $\left(M=0.06291 \mathrm{DBH}^{2.4841}\right)$, and carbon stock in the stands was estimated by considering the carbon contents of tree dry biomasses (around 50\%) [27].

Soil properties. To determine the bulk density, $\mathrm{pH}$, total carbon $(\mathrm{C})$, and nitrogen $(\mathrm{N})$ concentrations of the soil in the stand, three soil samples were collected from each plot. Soil bulk density was obtained by the volumetric ring method [28]. Soil $\mathrm{pH}$ was measured by 1:5 dry soil: $\mathrm{CaCl}_{2}$ solution $(0.01 \mathrm{M})$ [29]. The total soil $\mathrm{C}$ and $\mathrm{N}$ concentrations were determined by using an elemental analysis-stable isotope ratio mass spectrometer (Vario ELIII Elementar, Hessen Langenselbold, Germany).

Table 1. Selected sites and soil characteristics for three stands in Dongping National Park, Chongming Island.

\begin{tabular}{|c|c|c|c|}
\hline & 10-Year-Old Stand & 17-Year-Old Stand & 32-Year-Old Stand \\
\hline \multicolumn{4}{|c|}{ Tree Growth } \\
\hline Tree density (stems/ha) & 1050 & 725 & 550 \\
\hline Average height (m) & $8.1 \pm 1.5$ & $16.2 \pm 2.2$ & $28.3 \pm 3.4$ \\
\hline Biomass carbon stock $\left(\mathrm{t} \mathrm{ha}^{-1}\right)$ & 13.96 & 29.76 & 64.93 \\
\hline \multicolumn{4}{|c|}{ Litter $^{\text {(a) }}$} \\
\hline Fallen branch C (\%) & $44.40 \pm 0.33$ & $44.86 \pm 0.32$ & $46.07 \pm 0.37$ \\
\hline Fallen leaf N (\%) & $1.60 \pm 0.09$ & $1.84 \pm 0.05$ & $1.69 \pm 0.08$ \\
\hline Fallen branch N (\%) & $0.75 \pm 0.04$ & $0.63 \pm 0.04$ & $0.64 \pm 0.05$ \\
\hline Fallen leaf C:N ratio & 29.6 & 26.1 & 28.2 \\
\hline Fallen branch C:N ratio & 59.2 & 71.2 & 72.0 \\
\hline \multicolumn{4}{|c|}{ Soil Properties } \\
\hline $\mathrm{C}: \mathrm{N}$ ratio & 13 & 10 & 10 \\
\hline Soil carbon storage $\left(\mathrm{t} \mathrm{ha}^{-1}\right)$ & $31.87 \pm 2.20$ & $37.68 \pm 1.07$ & $40.01 \pm 2.49$ \\
\hline
\end{tabular}

Note: (a) The source of litter data was Xiao's dissertation [30]. DBH, diameter at breast height; SOC, soil organic carbon. 


\subsection{Measurements}

\subsubsection{Soil Gas Emissions}

Gas emission measurements were based on Forestry Standards "Observation Methodology for Long-term Forest Ecosystem Research" of PR China (LY/T 1952-2011). Because the forest sites were relatively homogeneous, three observation points were systematically arranged in each stand. The static chamber method was employed to measure soil $\mathrm{CO}_{2}, \mathrm{CH}_{4}$, and $\mathrm{N}_{2} \mathrm{O}$ emissions. Gas emissions were measured every two weeks (September 2011-September 2013).

The static chamber consisted of two parts. First, the stainless steel based part $(0.5 \mathrm{~m} \times 0.5 \mathrm{~m} \times 0.2 \mathrm{~m})$ was permanently inserted at a $10 \mathrm{~cm}$ depth in the soil for each observation point of the plots, and the second upper part was made of a polyvinyl chloride plate with a size of $0.5 \mathrm{~m} \times 0.5 \mathrm{~m} \times 0.5 \mathrm{~m}$. A fan was installed in each upper chamber for air mixing. Next, 30 min after closing the chamber, gas samples were collected with a gastight syringe $(100 \mathrm{~mL})$ every $10 \mathrm{~min}$ for the next $40 \mathrm{~min}$ (0, $10 \mathrm{~min}, 20 \mathrm{~min}, 30 \mathrm{~min}$, and $40 \mathrm{~min}$ ). Five gas samples at each observation point were taken between 9:00 a.m. and 12:00 a.m. and analyzed by gas chromatography (6890N, Agilent, Santa Clara, CA, USA) with an Electron Capture Detector (ECD) for $\mathrm{N}_{2} \mathrm{O}$ detection and an Flame Ionization Detector (FID) for $\mathrm{CH}_{4}$ and $\mathrm{CO}_{2}$ detection [31,32]. The minimum detectable limit of $\mathrm{CO}_{2}, \mathrm{CH}_{4}$, and $\mathrm{N}_{2} \mathrm{O}$ fluxes were $0.3 \mathrm{mg} \mathrm{C} \mathrm{m}^{-2} \mathrm{~h}^{-1}, 4.4 \mu \mathrm{g} \mathrm{C} \mathrm{m}{ }^{-2} \mathrm{~h}^{-1}$, and $0.3 \mu \mathrm{g} \mathrm{N} \mathrm{m} \mathrm{N}^{-2} \mathrm{~h}^{-1}$, respectively [33]. The gas emissions were calculated by the rate of gas concentration change during sampling. The calculation details were as follows.

$$
F=\frac{d C}{d t} \times \frac{m P V}{A R T}=H \times \frac{d C}{d t} \times \frac{m P}{R T}
$$

where $F$ is the gas emissions ( $\mathrm{mg} \mathrm{m}^{-2} \mathrm{~h}^{-1}$ for $\mathrm{CO}_{2}$ and $\mathrm{CH}_{4}$, and $\mu \mathrm{g} \mathrm{m}^{-2} \mathrm{~h}^{-1}$ for $\mathrm{N}_{2} \mathrm{O}$ ), and $\frac{d C}{d t}$ ( $\mu \mathrm{L} \mathrm{L}^{-1} \mathrm{~min}^{-1}$ for $\mathrm{CO}_{2}$ and $\mathrm{CH}_{4}$, and $\mathrm{nL} \mathrm{L}^{-1} \mathrm{~min}^{-1}$ for $\mathrm{N}_{2} \mathrm{O}$ ) is the emission rate of $\mathrm{CO}_{2}, \mathrm{CH}_{4}$, or $\mathrm{N}_{2} \mathrm{O}$ concentration in the chamber. A linear regression is used to calculate the emission rate. The $m$ $\left(\mathrm{g} \mathrm{mol}^{-1}\right)$ is the molecular weight of trace gas. $P$ indicates the atmospheric pressure $\left(P=1.013 \times 10^{5} \mathrm{~Pa}\right) . R$ is the gas constant $\left(R=8.314 \mathrm{~J} \mathrm{~mol}^{-1} \mathrm{~K}^{-1}\right) . T(\mathrm{~K})$ is the air temperature in the chamber. $V\left(\mathrm{~cm}^{3}\right), H(\mathrm{~cm})$, and $A\left(\mathrm{~cm}^{2}\right)$ are the volume, height, and area of the static chamber, respectively.

\subsubsection{Soil Temperature and Soil Water Content}

The probe of digital thermometer JM 624 (Jinming Insturment Co., LTD, Tianjin, China) was inserted at 5 and $10 \mathrm{~cm}$ soil depth to detect the soil temperature on the outside of each chamber when we collected the gas samples. Soil samples were taken by soil auger from $0 \mathrm{~cm}$ to $10 \mathrm{~cm}$ and $10 \mathrm{~cm}$ to $20 \mathrm{~cm}$ depths to determine soil water contents gravimetrically by measuring the fresh and dry weights after drying in an oven at $105{ }^{\circ} \mathrm{C}$ for two days.

\subsection{Data Analysis}

Generally, the growing season of dawn redwood in Shanghai is from May to November, and the non-growing season is from December to April. We split our observed data into two parts according to the growing or non-growing season to determine whether soil respiration increases simultaneously with increasing photosynthesis.

\subsection{1. $Q_{10}$ Values}

The temperature sensitivity of the soil respiration rate at the three stands was calculated by a non-linear regression model with the van't Hoff function, as follows:

$$
R_{S}=\alpha e^{\beta T},
$$


where $R_{S}$ is the soil respiration $\left(\mathrm{mg} \mathrm{CO} \mathrm{CO}_{2} \mathrm{~m}^{-2} \mathrm{~h}^{-1}\right), \alpha$ and $\beta$ are fitted constants, and $T$ is soil temperature, which was measured at $5 \mathrm{~cm}$ and $10 \mathrm{~cm}$ depths in the soil [34,35]. $Q_{10}$ is the factor explaining the temperature sensitivity of soil respiration, and it is calculated as follows: $Q_{10}=e^{10 \beta}[36,37]$.

\subsubsection{The Relationship between GHG Emissions and Environmental Factors}

One-sample Kolmogorov-Smirnov testing was used to determine whether the GHG emissions, soil temperature, and soil moisture were normally distributed. Soil temperature and soil moisture were normally distributed. Data variation among the sites was tested for significance by using the Duncan test following ANOVA. Pearson correlation analyses were used to analyze the relationship between greenhouse gas and the environment factors. Statistical analysis was conducted using IBM SPSS Statistics 21 software.

Canonical correspondence analysis (CCA) was conducting by using the CCA procedure in PAST 3 to detect the relationship between soil GHG emissions and environmental factors, such as soil temperature, soil water content, soil $\mathrm{C}$ and $\mathrm{N}$ concentration, and foliage $\mathrm{C}$ and $\mathrm{N}$ concentrations. A plot of the first two canonical variables (Can 1 and Can 2) was made to visually show the correlation among gases and environmental variables.

\section{Results}

\subsection{Soil Respiration Rate}

During the experimental period of 2011 to 2013, the mean $\mathrm{CO}_{2}$ emission rate was $228.30 \pm 142.40 \mathrm{mg} \mathrm{m}^{-2} \mathrm{~h}^{-1}, 238.14 \pm 142.20 \mathrm{mg} \mathrm{m}^{-2} \mathrm{~h}^{-1}$, and $297.71 \pm 218.09 \mathrm{mg} \mathrm{m}^{-2} \mathrm{~h}^{-1}$ in the 10,17, and 32-year-old stands, respectively (Table 2). Maximum soil $\mathrm{CO}_{2}$ emissions were observed in May and August in every year, and the smallest emissions in January and February (Figure 2). The mean soil $\mathrm{CO}_{2}$ emissions were $346.47 \pm 164.23 \mathrm{mg} \mathrm{m}^{-2} \mathrm{~h}^{-1}$ and $117.09 \pm 52.34 \mathrm{mg} \mathrm{m}^{-2} \mathrm{~h}^{-1}$ in the growing season and non-growing season, respectively (Figure 3).

Table 2. Average forest soil $\mathrm{CO}_{2}, \mathrm{CH}_{4}$, and $\mathrm{N}_{2} \mathrm{O}$ emissions measured in the 10, 17, and 32-year-old stands during the period from 2011-2013.

\begin{tabular}{ccccc}
\hline & Stand Age & 2011-2012 & 2012-2013 & 2011-2013 \\
\hline \multirow{2}{*}{$\mathrm{CH}_{4}\left(\mathrm{mg} \mathrm{m}^{-2} \mathrm{~h}^{-1}\right)$} & 10 & $-0.030 \pm 0.029 \mathrm{~b}$ & $-0.021 \pm 0.016 \mathrm{~b}$ & $-0.026 \pm 0.024 \mathrm{~b}$ \\
& 17 & $-0.035 \pm 0.059 \mathrm{~b}$ & $-0.030 \pm 0.025 \mathrm{~b}$ & $-0.032 \pm 0.045 \mathrm{~b}$ \\
& 32 & $-0.081 \pm 0.093 \mathrm{a}$ & $-0.056 \pm 0.049 \mathrm{a}$ & $-0.069 \pm 0.075 \mathrm{a}$ \\
\hline & 10 & $233.35 \pm 152.28 \mathrm{a}$ & $223.25 \pm 134.76 \mathrm{a}$ & $228.30 \pm 142.40 \mathrm{a}$ \\
$\mathrm{CO}_{2}\left(\mathrm{mg} \mathrm{m}^{-2} \mathrm{~h}^{-1}\right)$ & 17 & $250.42 \pm 146.93 \mathrm{a}$ & $225.86 \pm 139.22 \mathrm{a}$ & $238.14 \pm 142.20 \mathrm{a}$ \\
& 32 & $322.40 \pm 241.16 \mathrm{a}$ & $273.01 \pm 194.12 \mathrm{a}$ & $297.71 \pm 218.09 \mathrm{a}$ \\
\hline & 10 & $7.17 \pm 16.12 \mathrm{a}$ & $3.40 \pm 6.05 \mathrm{a}$ & $5.29 \pm 12.20 \mathrm{a}$ \\
$\mathrm{N}_{2} \mathrm{O}\left(\mu \mathrm{g} \mathrm{m}^{-2} \mathrm{~h}^{-1}\right)$ & 17 & $15.79 \pm 29.95 \mathrm{a}$ & $4.38 \pm 6.68 \mathrm{a}$ & $10.09 \pm 22.23 \mathrm{a}$ \\
& 32 & $15.46 \pm 19.23 \mathrm{a}$ & $9.04 \pm 7.56 \mathrm{~b}$ & $12.25 \pm 14.82 \mathrm{a}$ \\
\hline
\end{tabular}

Note: The periods of 2011-2012 and 2012-2013 are 15 September 2011-1 September 2012 and 14 September 2012-2 September 2013, respectively. The contents in this table refer to mean average greenhouse gas emissions \pm standard deviation. Different lower case letters after these contents indicate significant differences between the treatments, each with $p<0.05$. 


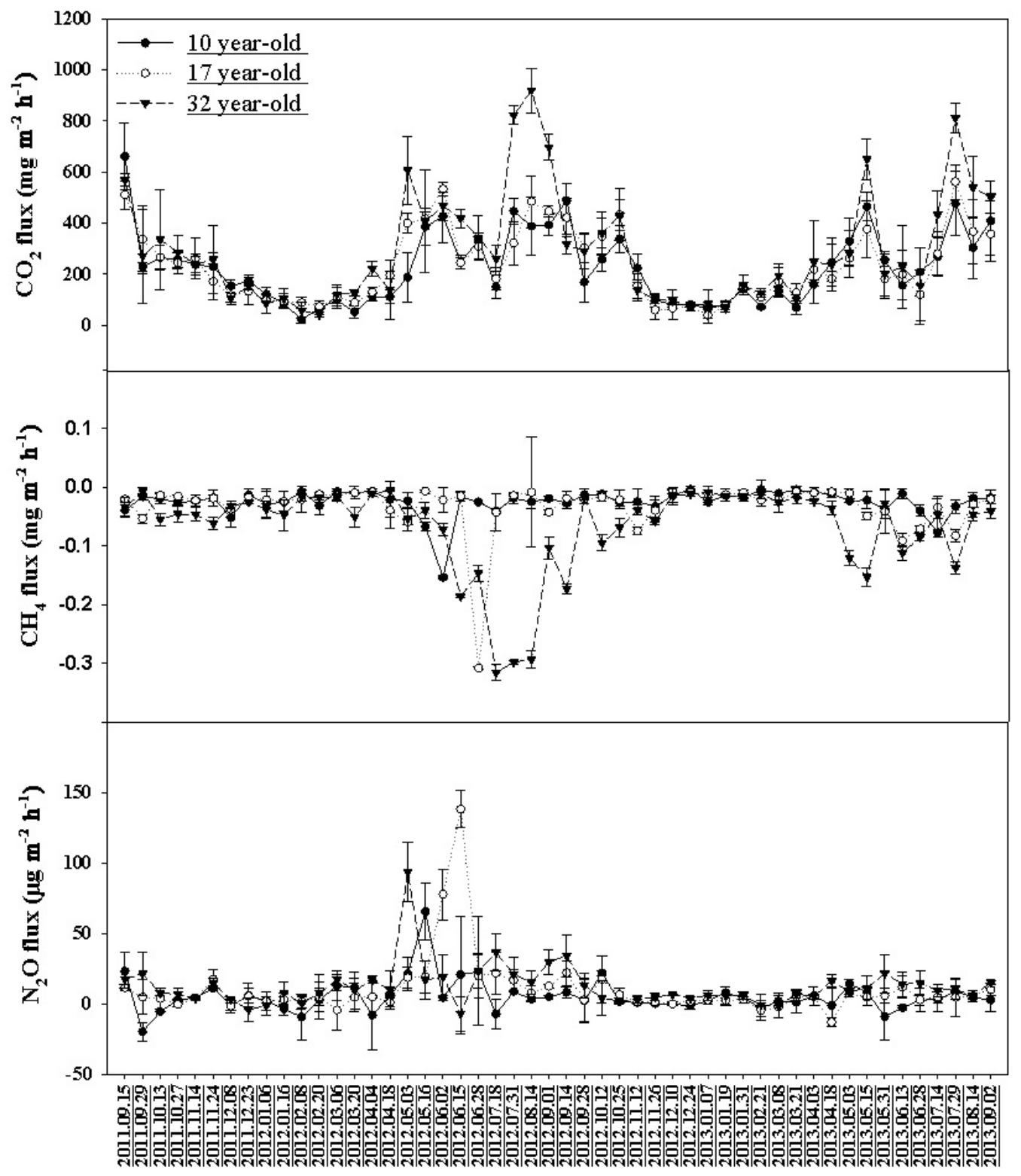

Figure 2. Soil $\mathrm{CO}_{2}, \mathrm{CH}_{4}$, and $\mathrm{N}_{2} \mathrm{O}$ emissions measured in 10, 17, and 32-year-old stands during 2011-2013. The error bars shown in the figure are standard deviations.

\subsection{Soil $\mathrm{CH}_{4}$ Uptake}

The soil was a sink of $\mathrm{CH}_{4}$ in all three stands, with the highest uptake of $\mathrm{CH}_{4}$ occurring in the summer (Figure 2). During 2011-2013, the mean soil $\mathrm{CH}_{4}$ uptake rates were $0.026 \mathrm{mg} \mathrm{m}^{-2} \mathrm{~h}^{-1}$, $0.032 \mathrm{mg} \mathrm{m}^{-2} \mathrm{~h}^{-1}$, and $0.069 \mathrm{mg} \mathrm{m}^{-2} \mathrm{~h}^{-1}$ in the 10,17, and 32-year-old stands, respectively (Table 2). The $\mathrm{CH}_{4}$ uptake rates were significantly higher in the older stand compared to the younger stands $(p<0.05)$. The highest $\mathrm{CH}_{4}$ uptakes were measured in the growing season (Figure 3).

\subsection{Soil $\mathrm{N}_{2} \mathrm{O}$ Emission}

There were large differences in $\mathrm{N}_{2} \mathrm{O}$ emissions among the three stands, ranging from $-19.78 \mu \mathrm{g} \mathrm{m}^{-2} \mathrm{~h}^{-1}$ to $65.39 \mu \mathrm{g} \mathrm{m}^{-2} \mathrm{~h}^{-1},-13.02 \mu \mathrm{g} \mathrm{m}^{-2} \mathrm{~h}^{-1}$ to $138.00 \mu \mathrm{g} \mathrm{m}^{-2} \mathrm{~h}^{-1}$, and $-6.98 \mu \mathrm{g} \mathrm{m}^{-2} \mathrm{~h}^{-1}$ to $93.45 \mu \mathrm{g} \mathrm{m}^{-2} \mathrm{~h}^{-1}$ in the 10, 17, and 32-year-old stands, respectively (Figure 2). The mean $\mathrm{N}_{2} \mathrm{O}$ emissions were $5.29,10.09$, and $12.25 \mu \mathrm{g} \mathrm{m}^{-2} \mathrm{~h}^{-1}$, respectively (Table 2), thereby showing that the older stand had larger $\mathrm{N}_{2} \mathrm{O}$ emissions compared with the younger stands, but it was not significant 
( $p=0.113$ ). The $\mathrm{N}_{2} \mathrm{O}$ emissions were higher during the growing season compared to the non-growing season $(p<0.05)$ (Figure 3).

Whole Year
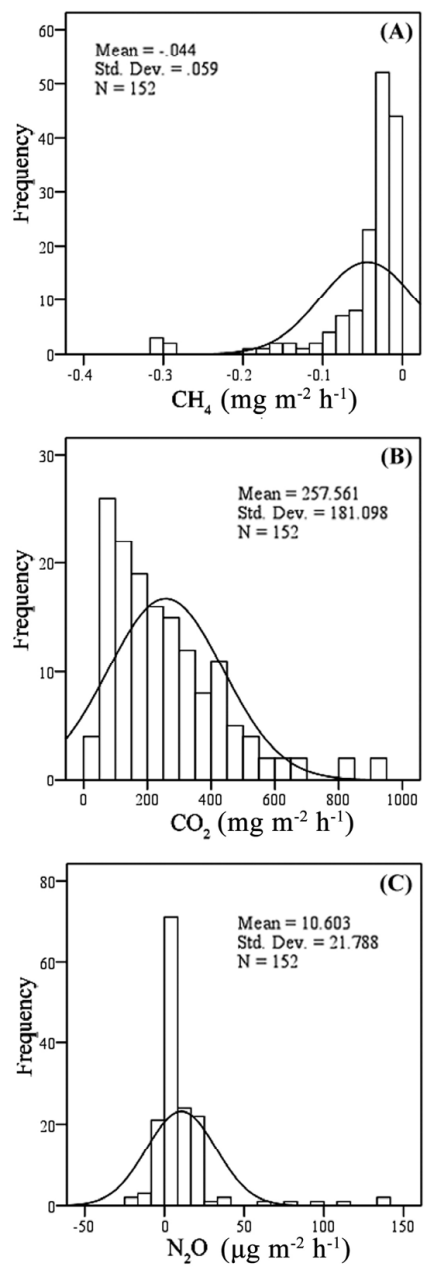

Growing Season
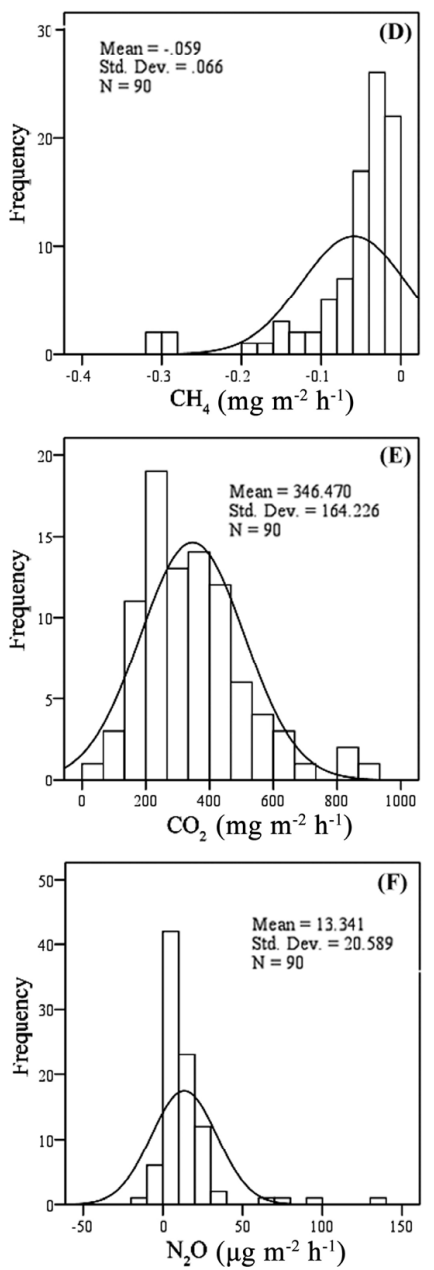

Non-growing Season
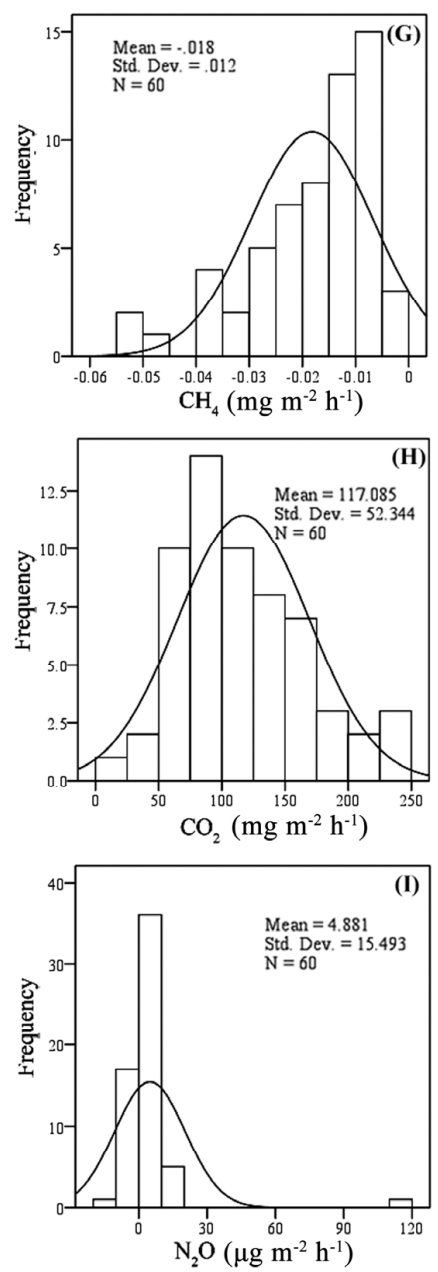

Figure 3. The frequency distribution histogram of $\mathrm{CH}_{4}, \mathrm{CO}_{2}$, and $\mathrm{N}_{2} \mathrm{O}$ emissions during the whole year, growing season (from 1 May to 30 November), and non-growing season (from 1 December to 30 April), respectively. (A-C) in the upper-right corner represent the greenhouse gas (GHG) emissions during the whole year; (D-F) represent the GHG emissions during the growing season; and (G-I) represent the GHG emissions during the non-growing season.

\subsection{Annual GHG Emissions}

The annual $\mathrm{CO}_{2}$ emissions were significantly higher in the 32-year-old stand compared to the other two younger stands $(p<0.05)$ (Figure 4$)$. The emissions were $23.3 \%$ and $20.0 \%$ higher in the 32-year-old stand than those in the 10 and 17-year-old stands, respectively. Moreover, the annual soil $\mathrm{CH}_{4}$ uptake had significant differences among the three stands. The annual $\mathrm{CH}_{4}$ uptake was highest in the 32-year-old stand and lowest in the 10-year-old stand.

The highest annual soil $\mathrm{N}_{2} \mathrm{O}$ emission was observed in the 32-year-old stand and we noted that the 32-year-old stand had a $56.8 \%$ higher annual $\mathrm{N}_{2} \mathrm{O}$ emission than the 10 -year-old stand and a $17.7 \%$ higher annual emission than the 17-year-old stand. However, the $\mathrm{N}_{2} \mathrm{O}$ emissions among the three stands were not significantly different. 

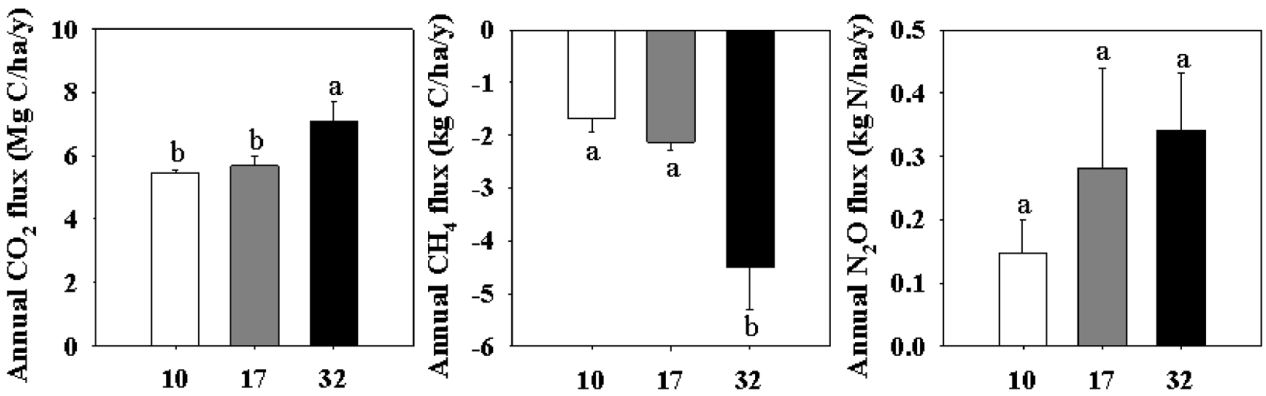

Figure 4. Annual cumulative $\mathrm{CO}_{2}, \mathrm{CH}_{4}$, and $\mathrm{N}_{2} \mathrm{O}$ emissions measured during 2011 to 2013. Symbols on the $x$-axis $(10,17$, and 32) mean the 10-year-old, 17-year-old, and 32-year-old stands. (Error bars in the figures means standard error, and different lower case letters indicate significant differences between the treatments, each with $p<0.05)$.

\subsection{The Effect of Soil Temperature on GHG Emissions}

In this research, soil $\mathrm{CO}_{2}$ emissions increased exponentially with soil temperature both at $5 \mathrm{~cm}$ and at $10 \mathrm{~cm}$ soil depths $\left(R_{S}=62.78 e^{0.075 T}\right.$ at $5 \mathrm{~cm}$ soil depth, and $R_{S}=61.89 e^{0.077 T}$ at $10 \mathrm{~cm}$ soil depth $)$. The exponential model could explain $68 \%$ or $69 \%(p<0.001)$ of the seasonal variation in soil $\mathrm{CO}_{2}$ emissions (Table 3). The $Q_{10}$ values were calculated to be 2.12 and 2.15 at $5 \mathrm{~cm}$ and at $10 \mathrm{~cm}$ soil depths, respectively (Table 3). Usually, $Q_{10}$-values were almost $3 \%-51 \%$ higher in the non-growing season than in the growing season.

Table 3. Parameters of the exponential model for soil $\mathrm{CO}_{2}$ emissions as a function of soil temperature at 5 and $10 \mathrm{~cm}$ depths in the three stands.

\begin{tabular}{|c|c|c|c|c|c|c|c|c|c|}
\hline \multirow{2}{*}{\multicolumn{2}{|c|}{$\begin{array}{c}\text { Sites } \\
\text { Soil Depth }(\mathrm{cm})\end{array}$}} & \multicolumn{2}{|c|}{ 10-Year-Old Stand } & \multicolumn{2}{|c|}{ 17-Year-Old Stand } & \multicolumn{2}{|c|}{ 32-Year-Old Stand } & \multicolumn{2}{|c|}{ Three Stands } \\
\hline & & 5 & 10 & 5 & 10 & 5 & 10 & 5 & 10 \\
\hline $\begin{array}{l}\text { Whole } \\
\text { Year }\end{array}$ & $\begin{array}{c}R^{2} \\
\alpha \\
\beta \\
Q_{10} \\
\end{array}$ & $\begin{array}{c}0.58 \\
67.61 \\
0.0659 \\
1.93\end{array}$ & $\begin{array}{c}0.65 \\
59.71 \\
0.0752 \\
2.12\end{array}$ & $\begin{array}{c}0.72 \\
62.01 \\
0.0732 \\
2.08\end{array}$ & $\begin{array}{c}0.66 \\
65.99 \\
0.0689 \\
1.99\end{array}$ & $\begin{array}{c}0.79 \\
58.23 \\
0.0872 \\
2.39\end{array}$ & $\begin{array}{c}0.78 \\
60.60 \\
0.0856 \\
2.35\end{array}$ & $\begin{array}{c}0.68 \\
62.78 \\
0.0752 \\
2.12\end{array}$ & $\begin{array}{c}0.69 \\
61.89 \\
0.0767 \\
2.15\end{array}$ \\
\hline $\begin{array}{l}\text { Growing } \\
\text { Season }\end{array}$ & $\begin{array}{c}R^{2} \\
\alpha \\
\beta \\
Q_{10}\end{array}$ & $\begin{array}{c}0.24 \\
132.36 \\
0.0383 \\
1.47\end{array}$ & $\begin{array}{c}0.23 \\
129.40 \\
0.0397 \\
1.49\end{array}$ & $\begin{array}{c}0.36 \\
89.30 \\
0.0569 \\
1.77\end{array}$ & $\begin{array}{c}0.23 \\
113.75 \\
0.0448 \\
1.57\end{array}$ & $\begin{array}{c}0.52 \\
77.02 \\
0.0746 \\
2.11\end{array}$ & $\begin{array}{c}0.51 \\
84.09 \\
0.0708 \\
2.03\end{array}$ & $\begin{array}{c}0.36 \\
96.82 \\
0.0568 \\
1.76\end{array}$ & $\begin{array}{c}0.69 \\
61.89 \\
0.0767 \\
2.15\end{array}$ \\
\hline $\begin{array}{l}\text { Non-growing } \\
\text { Season }\end{array}$ & $\begin{array}{c}R^{2} \\
\alpha \\
\beta \\
Q_{10}\end{array}$ & $\begin{array}{c}0.18 \\
71.56 \\
0.036 \\
1.43\end{array}$ & $\begin{array}{c}0.33 \\
51.86 \\
0.0811 \\
2.25\end{array}$ & $\begin{array}{c}0.59 \\
55.85 \\
0.0808 \\
2.24\end{array}$ & $\begin{array}{c}0.54 \\
55.52 \\
0.0824 \\
2.28\end{array}$ & $\begin{array}{c}0.61 \\
53.15 \\
0.0947 \\
2.58\end{array}$ & $\begin{array}{c}0.57 \\
52.70 \\
0.0986 \\
2.68\end{array}$ & $\begin{array}{c}0.35 \\
65.24 \\
0.0599 \\
1.82\end{array}$ & $\begin{array}{c}0.69 \\
61.89 \\
0.0767 \\
2.15\end{array}$ \\
\hline
\end{tabular}

$\mathrm{CH}_{4}$ uptakes and $\mathrm{N}_{2} \mathrm{O}$ emissions were significantly correlated with soil temperature at both $5 \mathrm{~cm}$ and $10 \mathrm{~cm}$ depths. There was a positive correlation between the $\mathrm{CH}_{4}$ uptake and soil temperature (Pearson correlation, -0.3 ). In addition, $\mathrm{N}_{2} \mathrm{O}$ and soil temperature had a positive correlation (Pearson Correlation, 0.3) (shown in Table 4).

Table 4. Pearson correlation coefficients between greenhouse gas and soil temperature and water content.

\begin{tabular}{|c|c|c|c|c|c|c|c|}
\hline & $\mathrm{CH}_{4}$ & $\mathrm{CO}_{2}$ & $\mathrm{~N}_{2} \mathrm{O}$ & $T 5 \mathrm{~cm}$ & $T 10 \mathrm{~cm}$ & SWC 0-10 cm & SWC $10-20 \mathrm{~cm}$ \\
\hline $\begin{array}{c}\mathrm{CH}_{4} \\
\mathrm{CO}_{2} \\
\mathrm{~N}_{2} \mathrm{O} \\
T 5 \mathrm{~cm} \\
T 10 \mathrm{~cm} \\
\text { SWC } 0-10 \mathrm{~cm} \\
\text { SWC } 10-20 \mathrm{~cm}\end{array}$ & 1.000 & $\begin{array}{c}-0.377^{* *} \\
1.000\end{array}$ & $\begin{array}{c}-0.041 \\
0.380 \\
1.000\end{array}$ & $\begin{array}{r}-0.301^{* *} \\
0.765^{* *} \\
0.274^{* *} \\
1.000\end{array}$ & $\begin{array}{r}-0.317^{* *} \\
0.776^{* *} \\
0.274^{* *} \\
0.972^{* *} \\
1.000\end{array}$ & $\begin{array}{l}-0.012 \\
-0.211 * \\
0.141 \\
-0.319 \text { ** } \\
-0.324 \text { ** } \\
1.000\end{array}$ & $\begin{array}{l}0.169 \\
-0.276^{\text {** }} \\
-0.047 \\
-0.364^{* *} \\
-0.385^{* *} \\
0.671^{* *} \\
1.000\end{array}$ \\
\hline
\end{tabular}

Note: ${ }^{* *}$ Correlation is significant at the 0.01 level (2-tailed). ${ }^{*}$ Correlation is significant at the 0.05 level (2-tailed). $T 5 \mathrm{~cm}$ and $T 10 \mathrm{~cm}$ mean soil temperature at $5 \mathrm{~cm}$ soil depth and at $10 \mathrm{~cm}$ soil depth, respectively. SWC $0-10 \mathrm{~cm}$ and SWC $10-20 \mathrm{~cm}$ mean soil water content at $0-10 \mathrm{~cm}$ soil depth and at $10-20 \mathrm{~cm}$ soil depth, respectively. 


\subsection{Effects of Soil Water Content on GHG Emissions}

Soil water content contributed substantially to the GHG emissions. The relationship between soil $\mathrm{CO}_{2}$ emissions and soil water content at both $0-10 \mathrm{~cm}$ and $10-20 \mathrm{~cm}$ depths was negative. However, no significant relationship was found between $\mathrm{CH}_{4}$ emission and soil water content, or $\mathrm{N}_{2} \mathrm{O}$ emission and soil water content. (Table 4).

\subsection{The Main Influencing Factors of Soil Greenhouse Gas Emissions}

The variations in vegetation carbon, nitrogen, and soil properties were described by two significant canonical components (explaining 100\% of the variance) (Figure 5). The first, Can 1, accounted for $98.65 \%$ of the total variance and was highly related to the trees' biomass, and C and $\mathrm{N}$ content in soil and foliage. Can 2 accounted for $1.21 \%$ of the total variance with close correlation among soil water content and soil temperature. The $\mathrm{CO}_{2}$ and $\mathrm{N}_{2} \mathrm{O}$ emissions, and $\mathrm{CH}_{4}$ uptake all have positive correlations with Can 1 and negative correlations with Can 2.

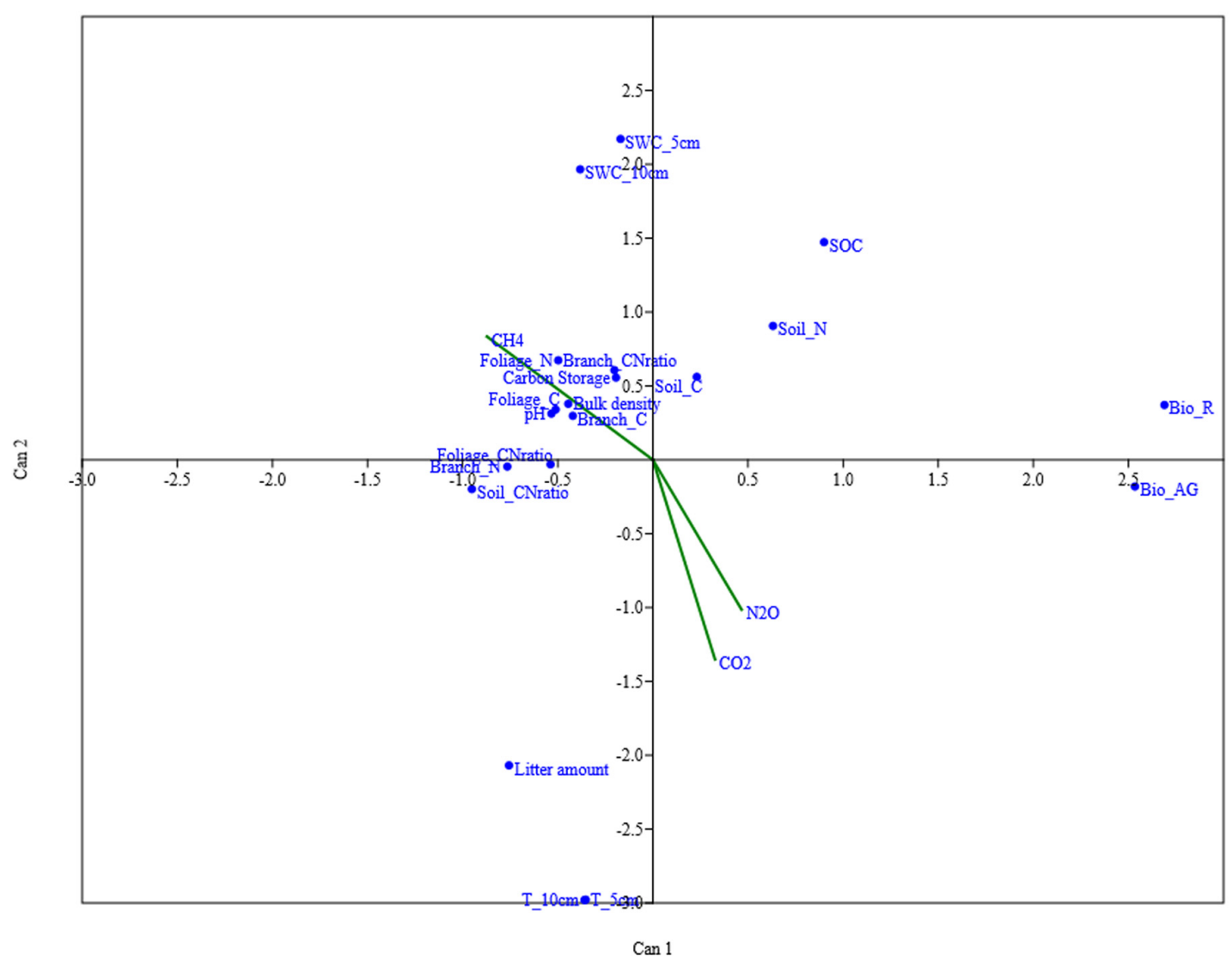

Figure 5. GHG emissions defined by the first two canonical variables (Can 1 and Can 2) extracted from the canonical correspondence analysis (CCA). In this plot, the position of points relative to the direction of vectors approximates correlations between soil GHG emissions and environmental factors. Vector length indicates the overall contribution of the variables to the analysis, and vector direction indicates the correlation of the variables with each axis.

\section{Discussion}

\subsection{Soil Carbon Dynamic in Different-Age Stands}

The soil was a source of $\mathrm{CO}_{2}$ and sink of $\mathrm{CH}_{4}$ in the three stands in both growing and non-growing seasons. The annual soil $\mathrm{CO}_{2}$ emissions (5.5-7.1 $\mathrm{Mg} \mathrm{C} \mathrm{ha}^{-1}$ year $^{-1}$ ) were within the same range observed in other subtropical forests. For instance, annual soil $\mathrm{CO}_{2}$ emission was 
3.1-7.3 $\mathrm{Mg} \mathrm{C} \mathrm{ha}{ }^{-1}$ year $^{-1}$ in the seasonal tropical primary forests in Xishuangbanna region, southwest China, and from 3.1-7.3 to $11.1-12.0 \mathrm{MgC} \mathrm{ha}^{-1}$ year $^{-1}$ in the subtropical forests $[9,38]$. In subtropical and tropical forests, annual soil $\mathrm{CH}_{4}$ uptake rates ranged from $0.8 \mathrm{~kg} \mathrm{C} \mathrm{ha}^{-1}$ year ${ }^{-1}$ to $4.3 \mathrm{~kg} \mathrm{C} \mathrm{ha}^{-1}$ year $^{-1}$ [12,16,39]. Our study showed a similar uptake $\left(1.7 \mathrm{~kg} \mathrm{C} \mathrm{ha}^{-1}\right.$ year $^{-1}$ to $4.5 \mathrm{~kg} \mathrm{C} \mathrm{ha}^{-1}$ year $^{-1}$ ) in plantations located in northern subtropical areas, thereby suggesting that annual $\mathrm{CH}_{4}$ uptake does not significantly vary with subtropical or tropical biomes.

Soil $\mathrm{CO}_{2}$ significantly varied with soil temperature and water content in the three stands in both growing and non-growing seasons. A positive relationship existed between soil temperature and $\mathrm{CO}_{2}$ emission in these three stands, and a negative relationship was found between soil water content and $\mathrm{CO}_{2}$ emission. The effects of soil temperature and soil water content on $\mathrm{CO}_{2}$ emissions were statistically confounded. As such, we excluded the soil temperature effect through normalizing the soil respiration values with $R_{S}=62.78 e^{0.075 T}$ at $5 \mathrm{~cm}$ soil depth and $R_{S}=61.89 e^{0.077 T}$ at $10 \mathrm{~cm}$ soil depth, and found that the effect of soil water content on $\mathrm{CO}_{2}$ emissions was not significantly negative (with Pearson correlation from -0.18 to -0.19 ). Respiration rates generally decreased with decreasing water content. Soil temperature was probably the key factor regulating soil respiration. However, soil water content also restricted soil respiration [40]. Both soil $\mathrm{CO}_{2}$ emission and $\mathrm{CH}_{4}$ uptake peaked in the period of May-November because of the wet-hot climate. The laboratory and field studies have verified that soil temperature and soil water content could account for most of the seasonal variation in soil $\mathrm{CO}_{2}$ emission and $\mathrm{CH}_{4}$ uptake [40-42].

Soil temperature and water content explained $76 \%-87 \%$ of soil $\mathrm{CO}_{2}$ emission and $67 \%-75 \%$ of total annual emission in the wet season (April to September) of lower subtropical forests [6]. $Q_{10}$, an exponential relationship, has been commonly used to estimate soil respiration rates from soil temperature [36]. In previous literature, the mean $Q_{10}$ values were 2.14 for tropical regions and 2.26 for temperate regions [43]. In our study, $Q_{10}$ ranged from 1.9 to 2.4 during the whole year, and soil respiration in the non-growing season was more sensitive to soil temperature. The higher $Q_{10}$ in the non-growing season could be associated with the phonological cycle of photosynthesis as compared to the growing season, which has consequences on the belowground carbon allocation. In the summer, about $50 \%$ or more of the soil $\mathrm{CO}_{2}$ emissions could be originated from recently assimilated $C$, which trees allocate to the belowground system (root and rhizosphere) [44]. The values of $Q_{10}$ increased with soil depth, and this result was the same as that obtained by Pavelka [45]. The seasonal variation in soil temperature was lower in the deeper layers and soil respiration rate was relatively more sensitive to temperature fluctuations [46]. During the growing and non-growing seasons the different values of $Q_{10}$ were noted with different $R^{2}$ values, and the lower $R^{2}$ values were calculated in the growing season. During the growing season, soil temperature causes little changes in soil $\mathrm{CO}_{2}$ emissions. The primary reason might be the low temperature amplitude during the growing season. Second, the other factors (except soil temperature) could explain the soil $\mathrm{CO}_{2}$ emission such as the changes in photosynthesis and precipitation.

The soil temperature positively affected $\mathrm{CH}_{4}$ uptake, and no significant relationship existed between $\mathrm{CH}_{4}$ uptake and soil water content. Kiese and Werner observed that $\mathrm{CH}_{4}$ uptake was negatively correlated with soil temperature and soil water content $[38,39]$. In mid-subtropical China, the highest $\mathrm{CH}_{4}$ uptake (17.12 $\mathrm{g} \mathrm{C} \mathrm{ha}^{-1}$ day $^{-1}$ ) occurred in the summer-autumn season with increasing soil temperature and water content, but the relationships between $\mathrm{CH}_{4}$ uptake and soil temperature and $\mathrm{CH}_{4}$ uptake and soil water content were not significant [47]. In earlier studies, $\mathrm{CH}_{4}$ uptake had decreased with increasing soil water content during the summer season [48,49]. Maximum $\mathrm{CH}_{4}$ uptake rate was clearly associated with the lowest soil moisture and the highest soil temperature both in temperate and tropical forests [50]. Before oxidization by methanotrophs, the soil $\mathrm{CH}_{4}$ was emitted from anaerobic environments to the atmosphere. In the forest's soil, a certain amount of $\mathrm{CH}_{4}$ from the atmosphere was consumed by methanotrophs [51]. The optimum conditions for growth of methanotrophic bacteria and induction of methane oxidation activity were $20 \%-35 \%$ water contents and $25^{\circ} \mathrm{C}-35^{\circ} \mathrm{C}$ temperatures [52]. In our study, the water content ranged from $11 \%$ to $33 \%$, which was almost in the optimum range, and temperatures showed a larger range from $1.4{ }^{\circ} \mathrm{C}$ to $30^{\circ} \mathrm{C}$. Soil temperature could be more important than water content in regulating $\mathrm{CH}_{4}$ consumption in this study, which is in agreement with the results of previous reports [53]. 


\subsection{Soil Nitrogen Dynamic in Different-Aged Stands}

We observed highly dynamic $\mathrm{N}_{2} \mathrm{O}$ emissions with low values in our study (i.e., $0.81-1.87 \mathrm{~g} \mathrm{~N} \mathrm{ha}^{-1}$ day $^{-1}$ ), which were lower than some previously reported emissions. For example, our results are similar to the $\mathrm{N}_{2} \mathrm{O}$ emissions from undrained forests in southern Sweden (i.e., $1.62 \mathrm{~g} \mathrm{~N} \mathrm{ha}^{-1} \mathrm{day}^{-1}$ ) [54], but they are substantially lower than the $8.77 \mathrm{~g} \mathrm{~N} \mathrm{ha}^{-1} \mathrm{day}^{-1}$ previously recorded in the subtropical forest in southern China [12].

A seasonal variation in $\mathrm{N}_{2} \mathrm{O}$ emissions has been reported in tropical and subtropical forests. For instance, the highest $\mathrm{N}_{2} \mathrm{O}$ emissions have been observed during the spring and summer months with mean values of $2-5 \mathrm{~g} \mathrm{~N} \mathrm{ha}^{-1} \mathrm{day}^{-1}$. The lowest emissions were obtained during winter seasons, with less than $0.5 \mathrm{~g} \mathrm{~N} \mathrm{ha}^{-1}$ day $^{-1}$ [9]. The higher $\mathrm{N}_{2} \mathrm{O}$ emissions were emitted from temperate and tropical forest ecosystems during the wet and hot season [50]. The magnitude of $\mathrm{N}_{2} \mathrm{O}$ emissions was very closely linked to rainfall events [55]. The soil $\mathrm{N}_{2} \mathrm{O}$ was produced by microbes through nitrification in aerobic conditions and through denitrification under anaerobic conditions [56]. Factor, such as precipitation, was observed to exert some influence on the soil aeration, but soil aeration could affect $\mathrm{N}_{2} \mathrm{O}$ production. In our study, the highest soil $\mathrm{N}_{2} \mathrm{O}$ emissions were observed between May and November when higher rainfall occurred with a mean value of $2.04 \mathrm{~g} \mathrm{~N} \mathrm{ha}^{-1}$ day $^{-1}$. The lowest soil $\mathrm{N}_{2} \mathrm{O}$ emissions were recorded between December and April with a mean value of $0.75 \mathrm{~g} \mathrm{~N} h a^{-1}$ day $^{-1}$.

$\mathrm{N}_{2} \mathrm{O}$ emissions showed a positive correlation with soil temperature; no significant correlation with soil water content was observed, which was similar to a previous study in Japan [57]. However, some previous reports have shown that $\mathrm{N}_{2} \mathrm{O}$ emissions have a positive correlation with soil temperature and soil water content [42].

\subsection{Factors Affecting Soil Greenhouse Gas Emissions}

The present study showed that soil GHG emissions differed among the three stands. The 32-year-old stand had significantly higher $\mathrm{CO}_{2}$ emissions, $\mathrm{CH}_{4}$ uptake, and $\mathrm{N}_{2} \mathrm{O}$ emissions than the 10 and 17-year-old stands. Basically, these three stands differed in biomass/litter carbon storage, nitrogen content, and soil properties. The soil $\mathrm{CO}_{2}, \mathrm{~N}_{2} \mathrm{O}$, and $\mathrm{CH}_{4}$ were produced by microbial activity, and these processes were controlled by environmental factors [58,59].

Forest soil $\mathrm{CO}_{2}$ emissions were the sum of heterotrophic (microbes) and autotrophic respiration (roots), and the contribution of root respiration rates which were higher during the growing season [60]. The soil $\mathrm{CO}_{2}$ emissions were a good indicator of total below-ground allocation of carbon and of ecosystem productivity. Among these stands, the older stands maintained higher productivity than the younger stands; it was not surprising that the older stand had the highest rates of soil respiration. Older stands released higher $\mathrm{CO}_{2}$, and the major difference was that the older stand had higher soil carbon, which could probably reflect higher root and litter carbon storage [61]. The research in Loess Plateau of China [62] indicated that $48 \%$ of the variations in annual soil $\mathrm{CO}_{2}$ emissions were explained by the combined carbon stock in top soil and litter, $77 \%$ by the root carbon stock, and $63 \%$ by the combined carbon stock in roots, litter, and top soil. The aboveground litter mineralization and decomposition contributed to about $8 \%$ of the soil respiration in a subtropical Montane cloud forest in Taiwan [63]. In our study, the total carbon storage of litter, soil, and roots in the older stands was higher than the two younger stands, which indicated higher annual $\mathrm{CO}_{2}$ emissions in the older stands. Based on the principal component analyses, the litter composition was an important stimulator for soil $\mathrm{CO}_{2}$ emissions because of the simultaneous effects on production and consumption of the soil surface organic matter [64].

Methane emissions of soils were correlated with microbial activities, and the upper soil layer were generally $\mathrm{CH}_{4}$ sinks [65]. The rate of $\mathrm{CH}_{4}$ uptake was regulated by the soil $\mathrm{C}$ and $\mathrm{N}$ levels as well as soil water content, and there was a close link between labile $\mathrm{C}, \mathrm{N}$, and $\mathrm{CH}_{4}$ uptake in forest soils $[66,67]$. This research has shown that carbon and nitrogen contents of litter, soil, and root in older stands were higher than in younger stands, which indicates higher annual $\mathrm{CH}_{4}$ uptake in older stands. 
In contrast to the pattern of soil $\mathrm{CO}_{2}$ and $\mathrm{CH}_{4}$ emissions, no distinctly different trend in $\mathrm{N}_{2} \mathrm{O}$ emission was observed among differently aged stands. According to the reported study, soil $\mathrm{N}_{2} \mathrm{O}$ production and consumption were mainly influenced by the amount of mineral $\mathrm{N}$ in soils, and low $\mathrm{N}$ availability was linked with $\mathrm{N}_{2} \mathrm{O}$ emissions [2]. Highly dynamic emissions of $\mathrm{N}_{2} \mathrm{O}$ were found among different forest soil types [68]. The primary controlling factors of $\mathrm{N}_{2} \mathrm{O}$ production were found to be soil $\mathrm{pH}$ and $\mathrm{C} / \mathrm{N}$ ratio, and these soil properties could explain most of the variability of $\mathrm{N}_{2} \mathrm{O}$ emissions $[9,69]$. However, we used three stands in our study but the results indicating similar annual $\mathrm{N}_{2} \mathrm{O}$ emissions despite the different soil properties.

\section{Conclusions}

Soil respiration in each of the stands was strongly and positively related to soil temperature, and negatively related to soil water content. The soil $\mathrm{CH}_{4}$ uptake was positively related to soil temperature, and soil $\mathrm{N}_{2} \mathrm{O}$ emission had a positive relation with soil temperature. Affected by the annual climatic conditions (e.g., temperature and precipitation), soil respiration showed a clear seasonal variation, with high emissions in the wet-hot season (from May to November) and low emissions in the dry-cool season (from December to April).

Different stages of forest stands strongly affected soil respiration and $\mathrm{CH}_{4}$ emission rates through root respiration and/or microbial activities, but had no significant relationship with soil $\mathrm{N}_{2} \mathrm{O}$ emission. Carbon storage, nitrogen, and $\mathrm{C} / \mathrm{N}$ ratio (soil, litter, and root) were the main factors affecting $\mathrm{CH}_{4}$ uptake and $\mathrm{N}_{2} \mathrm{O}$ emission. Soil properties such as soil water content and soil $\mathrm{pH}$ were important indicators for soil respiration.

Acknowledgments: We thank Umair Muhammad for his language assistance. This research was co-funded by the National Natural Science Foundation of China (31400605), National Key Technology R\&D Program of China (2013BAD11B01), the National Natural Science Foundation of China (71333010), SJTU Agri-X Program (2014007), Shanghai Landscaping Administration Bureau (G141207), CFERN \& GENE Award Funds on Ecological Paper, and the Strategic Priority Research Program of the Chinese Academy of Sciences (XDA05050200).

Author Contributions: S.Y., G.S., and C.L. conceived and designed the experiments; S.Y., X.Z., and F.X. performed the experiments; X.Z. analyzed the data; S.Y., X.Z., and J.P. wrote this manuscript.

Conflicts of Interest: The authors declare no conflict of interest.

\section{References}

1. Lal, R. Forest soils and carbon sequestration. For. Ecol. Manag. 2005, 220, 242-258. [CrossRef]

2. Chapuis-Lardy, L.; Wrage, N.; Metay, A.; Chotte, J.; Bernoux, M. Soils, a sink for $\mathrm{N}_{2} \mathrm{O}$ ? A review. Glob. Chang. Biol. 2007, 13, 1-17. [CrossRef]

3. Carle, J.; Vuorinen, P.; Del Lungo, A. Status and trends in global forest plantation development. For. Prod. J. 2002, 52, 12-23.

4. Dai, L.; Wang, Y.; Su, D.; Zhou, L.; Yu, D.; Lewis, B.J.; Qi, L. Major forest types and the evolution of sustainable forestry in China. Environ. Manag. 2011, 48, 1066-1078. [CrossRef] [PubMed]

5. Central Committee of the Communist Party of China and China State Council. The Programming Outline for the Protection and Utilization of National Forestland (2010-2020); Central Committee of the Communist Party of China and China State Council: Beijing, China, 2010.

6. Zhang, D.; Sun, X.; Zhou, G.; Yan, J.; Wang, Y.; Liu, S.; Zhou, C.; Liu, J.; Tang, X.; Li, J. Seasonal dynamics of soil $\mathrm{CO}_{2}$ effluxes with responses to environmental factors in lower subtropical forests of China. Sci. China Ser. D Earth Sci. 2006, 49, 139-149. [CrossRef]

7. Yang, Y.; Chen, G.; Guo, J.; Xie, J.; Wang, X. Soil respiration and carbon balance in a subtropical native forest and two managed plantations. Plant Ecol. 2007, 193, 71-84. [CrossRef]

8. Iqbal, J.; Ronggui, H.; Lijun, D.; Lan, L.; Shan, L.; Tao, C.; Leilei, R. Differences in soil $\mathrm{CO}_{2}$ flux between different land use types in mid-subtropical China. Soil Biol. Biochem. 2008, 40, 2324-2333. [CrossRef]

9. Rowlings, D.; Grace, P.; Kiese, R.; Weier, K. Environmental factors controlling temporal and spatial variability in the soil-atmosphere exchange of $\mathrm{CO}_{2}, \mathrm{CH}_{4}$ and $\mathrm{N}_{2} \mathrm{O}$ from an Australian subtropical rainforest. Glob. Chang. Biol. 2012, 18, 726-738. [CrossRef] 
10. Hashimoto, S.; Tanaka, N.; Suzuki, M.; Inoue, A.; Takizawa, H.; Kosaka, I.; Tanaka, K.; Tantasirin, C.; Tangtham, N. Soil respiration and soil $\mathrm{CO}_{2}$ concentration in a tropical forest, Thailand. J. For. Res. 2004, 9, 75-79. [CrossRef]

11. Davidson, E.; Ishida, F.; Nepstad, D. Effects of an experimental drought on soil emissions of carbon dioxide, methane, nitrous oxide, and nitric oxide in a moist tropical forest. Glob. Chang. Biol. 2004, 10, 718-730. [CrossRef]

12. Tang, X.; Liu, S.; Zhou, G.; Zhang, D.; Zhou, C. Soil-atmospheric exchange of $\mathrm{CO}_{2}, \mathrm{CH}_{4}$, and $\mathrm{N}_{2} \mathrm{O}$ in three subtropical forest ecosystems in southern China. Glob. Chang. Biol. 2006, 12, 546-560. [CrossRef]

13. Yan, J.; Zhang, W.; Wang, K.; Qin, F.; Wang, W.; Dai, H.; Li, P. Responses of $\mathrm{CO}_{2}, \mathrm{~N}_{2} \mathrm{O}$ and $\mathrm{CH}_{4}$ fluxes between atmosphere and forest soil to changes in multiple environmental conditions. Glob. Chang. Biol. 2014, 20, 300-312. [CrossRef] [PubMed]

14. Dutaur, L.; Verchot, L.V. A global inventory of the soil $\mathrm{CH}_{4}$ sink. Glob. Biogeochem. Cycles 2007, 21, 7949-7950. [CrossRef]

15. Megonigal, J.P.; Guenther, A.B. Methane emissions from upland forest soils and vegetation. Tree Physiol. 2008, 28, 491-498. [CrossRef] [PubMed]

16. Wolf, K.; Flessa, H.; Veldkamp, E. Atmospheric methane uptake by tropical montane forest soils and the contribution of organic layers. Biogeochemistry 2012, 111, 469-483. [CrossRef]

17. Smith, K.; Ball, T.; Conen, F.; Dobbie, K.; Massheder, J.; Rey, A. Exchange of greenhouse gases between soil and atmosphere: Interactions of soil physical factors and biological processes. Eur. J. Soil Sci. 2003, 54, 779-791. [CrossRef]

18. Yan, Y.; Sha, L.; Cao, M.; Zheng, Z.; Tang, J.; Wang, Y.; Zhang, Y.; Wang, R.; Liu, G.; Wang, Y. Fluxes of ch4 and $\mathrm{n}_{2} \mathrm{o}$ from soil under a tropical seasonal rain forest in xishuangbanna, Southwest China. J. Environ. Sci. 2008, 20, 207-215. [CrossRef]

19. Moore, K.; Fitzjarrald, D.; Sakai, R.; Goulden, M.; Munger, J.; Wofsy, S. Seasonal variation in radiative and turbulent exchange at a deciduous forest in central massachusetts. J. Appl. Meteorol. 1996, 35, 122-134. [CrossRef]

20. Livesley, S.; Grover, S.; Hutley, L.; Jamali, H.; Butterbach-Bahl, K.; Fest, B.; Beringer, J.; Arndt, S. Seasonal variation and fire effects on $\mathrm{CH}_{4}, \mathrm{~N}_{2} \mathrm{O}$ and $\mathrm{CO}_{2}$ exchange in savanna soils of northern Australia. Agric. For. Meteorol. 2011, 151, 1440-1452. [CrossRef]

21. LePage, B.; Williams, C.; Yang, H. The Geobiology and Ecology of Metasequoia; Springer: Dordrecht, The Netherlands, 2005; Volume 22.

22. Chu, K.; Cooper, W. An ecological reconnaissance in the native home of Metasequoia glyptostroboides. Ecology 1950, 31, 260-278. [CrossRef]

23. Bajpai, V.; Rahman, A.; Kang, S. Chemical composition and anti-fungal properties of the essential oil and crude extracts of Metasequoia glyptostroboides miki ex hu. Ind. Crops Prod. 2007, 26, 28-35. [CrossRef]

24. Polman, J.; Michon, S.; Militz, H.; Helmink, A. The wood of Metasequoia glyptostroboides (hu et cheng) of dutch origin. Holz als Roh-und Werkstoff 1999, 57, 215-221. [CrossRef]

25. Bureau C.S.S. Chapter 1 Comprehensive. In Chongming Statistical Yearbook; Shanghai Statistics press: Chongming, Shanghai, China, 2016.

26. SMC. Shanghai Meteorological data. Available online: http://www.smb.gov.cn/ (accessed on 27 Feberury 2014).

27. Xiaver, B. Allometric Estimation of the Aboveground Biomass and Carbon in Metasequoia Glyptostroboide Plantations in Shanghai; Cranfield University: Bedfordshire, UK, 2009.

28. Pedrotti, A.; Pauletto, E.; Crestana, S.; Holanda, F.; Cruvinel, P.; Vaz, C. Evaluation of bulk density of albaqualf soil under different tillage systems using the volumetric ring and computerized tomography methods. Soil Tillage Res. 2005, 80, 115-123. [CrossRef]

29. Schofield, R.; Taylor, A. The measurement of soil pH. Soil Sci. Soc. Am. J. 1955, 19, 164-167. [CrossRef]

30. Xiao, C. Characteristics and Carbon-Storage Estimation of Metasequoia glyptostroboides Plantation Ecosystems at Different Age Stages in Chongming Island. Master' Dissertation, Shanghai Jiao Tong University, Shanghai, China, 2010.

31. Wang, Y.; Wang, Y.; Ling, H. A new carrier gas type for accurate measurement of $\mathrm{N}_{2} \mathrm{O}$ by GC-ECD. Adv. Atmos. Sci. 2010, 27, 1322-1330. [CrossRef] 
32. Zheng, X.; Mei, B.; Wang, Y.; Xie, B.; Wang, Y.; Dong, H.; Xu, H.; Chen, G.; Cai, Z.; Yue, J. Quantification of $\mathrm{n}_{2} \mathrm{O}$ fluxes from soil-plant systems may be biased by the applied gas chromatograph methodology. Plant Soil 2008, 311, 211-234. [CrossRef]

33. Yao, Z.; Wolf, B.; Chen, W.; Butterbach-Bahl, K.; Brüggemann, N.; Wiesmeier, M.; Dannenmann, M.; Blank, B.; Zheng, X. Spatial variability of $\mathrm{N}_{2} \mathrm{O}, \mathrm{CH}_{4}$ and $\mathrm{CO}_{2}$ fluxes within the xilin river catchment of inner mongolia, China: A soil core study. Plant Soil 2010, 331, 341-359. [CrossRef]

34. Hoff, J. Lectures on Theoretical and Physical Chemistry; Edward Arnold: London, UK, 1899.

35. Davidson, E.; Janssens, I. Temperature sensitivity of soil carbon decomposition and feedbacks to climate change. Nature 2006, 440, 165-173. [CrossRef] [PubMed]

36. Janssens, I.; Carrara, A.; Ceulemans, R. Annual $Q_{10}$ of soil respiration reflects plant phenological patterns as well as temperature sensitivity. Glob. Chang. Biol. 2004, 10, 161-169.

37. Zimmermann, M.; Bird, M.; Zechmeister-Boltenstern, S. $Q_{10}$ values of tropical forest soil respiration increases with ongoing decomposition. In Proceedings of the EGU General Assembly, Vienna, Austria, 22-27 April 2012; p. 4347.

38. Werner, C.; Zheng, X.; Tang, J.; Xie, B.; Liu, C.; Kiese, R.; Butterbach-Bahl, $\mathrm{K} . \mathrm{N}_{2} \mathrm{O}, \mathrm{CH}_{4}$ and $\mathrm{CO}_{2}$ emissions from seasonal tropical rainforests and a rubber plantation in Southwest China. Plant Soil 2006, 289, 335-353. [CrossRef]

39. Kiese, R.; Hewett, B.; Graham, A.; Butterbach-Bahl, K. Seasonal variability of $\mathrm{N}_{2} \mathrm{O}$ emissions and $\mathrm{CH}_{4}$ uptake by tropical rainforest soils of Queensland, Australia. Glob. Biogeochem. Cycles 2003, 17, 469-474. [CrossRef]

40. Davidson, E.; Belk, E.; Boone, R. Soil water content and temperature as independent or confounded factors controlling soil respiration in a temperate mixed hardwood forest. Glob. Chang. Biol. 1998, 4, $217-227$. [CrossRef]

41. Bowden, R.; Newkirk, K.; Rullo, G. Carbon dioxide and methane fluxes by a forest soil under laboratory-controlled moisture and temperature conditions. Soil Biol. Biochem. 1998, 30, 1591-1597. [CrossRef]

42. Schaufler, G.; Kitzler, B.; Schindlbacher, A.; Skiba, U.; Sutton, M.; Zechmeister-Boltenstern, S. Greenhouse gas emissions from european soils under different land use: Effects of soil moisture and temperature. Eur. J. Soil Sci. 2010, 61, 683-696. [CrossRef]

43. Tjoelker, M.; Oleksyn, J.; Reich, P. Modelling respiration of vegetation: Evidence for a general temperature-dependent $Q_{10}$. Glob. Chang. Biol. 2001, 7, 223-230. [CrossRef]

44. Högberg, P.; Read, D. Towards a more plant physiological perspective on soil ecology. Trends Ecol. Evol. 2006, 21, 548-554. [CrossRef] [PubMed]

45. Pavelka, M.; Acosta, M.; Marek, M.; Kutsch, W.; Janous, D. Dependence of the $Q_{10}$ values on the depth of the soil temperature measuring point. Plant Soil 2007, 292, 171-179. [CrossRef]

46. Lloyd, J.; Taylor, J. On the temperature dependence of soil respiration. Funct. Ecol. 1994, 8, 315-323. [CrossRef]

47. Chen, C.; Yang, Z.; Xie, J.; Liu, X.; Zhong, X. Seasonal variations of soil $\mathrm{CH}_{4}$ uptake rate in castanopsis carlesii forest in mid-subtropical China. J. Appl. Ecol. 2012, 23, 17-22.

48. Adamsen, A.; King, G. Methane consumption in temperate and subarctic forest soils: Rates, vertical zonation, and responses to water and nitrogen. Appl. Environ. Microbiol. 1993, 59, 485-490. [PubMed]

49. Singh, J.; Singh, S.; Raghubanshi, A.; Singh, S.; Kashyap, A.; Reddy, V. Effect of soil nitrogen, carbon and moisture on methane uptake by dry tropical forest soils. Plant Soil 1997, 196, 115-121. [CrossRef]

50. Luo, G.; Kiese, R.; Wolf, B.; Butterbach-Bahl, K. Effects of soil temperature and moisture on methane uptake and nitrous oxide emissions across three different ecosystem types. Biogeosciences 2013, 10, 3205-3219. [CrossRef]

51. Yavitt, J.; Downey, D.; Lang, G.; Sexston, A. Methane consumption in two temperate forest soils. Biogeochemistry 1990, 9, 39-52. [CrossRef]

52. Hanson, R.; Hanson, T.E. Methanotrophic bacteria. Microbiol. Rev. 1996, 60, 439-471. [PubMed]

53. Whalen, S.; Reeburgh, W. Moisture and temperature sensitivity of $\mathrm{CH}_{4}$ oxidation in boreal soils. Soil Biol. Biochem. 1996, 28, 1271-1281. [CrossRef]

54. Von Arnold, K.; Nilsson, M.; Hånell, B.; Weslien, P.; Klemedtsson, L. Fluxes of $\mathrm{CO}_{2}, \mathrm{CH}_{4}$ and $\mathrm{N}_{2} \mathrm{O}$ from drained organic soils in deciduous forests. Soil Biol. Biochem. 2005, 37, 1059-1071. [CrossRef] 
55. Breuer, L.; Papen, H.; Butterbach-Bahl, K. $\mathrm{N}_{2} \mathrm{O}$ emission from tropical forest soils of Australia. J. Geophys. Res. Atmos. 2000, 105, 26353-26367. [CrossRef]

56. Pihlatie, M.; Syväsalo, E.; Simojoki, A.; Esala, M.; Regina, K. Contribution of nitrification and denitrification to $\mathrm{N}_{2} \mathrm{O}$ production in peat, clay and loamy sand soils under different soil moisture conditions. Nutr. Cycl. Agroecosyst. 2004, 70, 135-141. [CrossRef]

57. Morishita, T.; Aizawa, S.; Yoshinaga, S.; Kaneko, S. Seasonal change in $\mathrm{N}_{2} \mathrm{O}$ flux from forest soils in a forest catchment in japan. J. For. Res. 2011, 16, 386-393. [CrossRef]

58. Gundersen, P.; Christiansen, J.; Alberti, G.; Brüggemann, N.; Castaldi, S.; Gasche, R.; Kitzler, B.; Klemedtsson, L.; Lobo-do-Vale, R.; Moldan, F. The response of methane and nitrous oxide fluxes to forest change in Europe. Biogeosciences 2012, 9, 3999-4012. [CrossRef]

59. Wang, H.; Liu, S.; Wang, J.; Shi, Z.; Lu, L.; Zeng, J.; Ming, A.; Tang, J.; Yu, H. Effects of tree species mixture on soil organic carbon stocks and greenhouse gas fluxes in subtropical plantations in China. For. Ecol. Manag. 2013, 300, 4-13. [CrossRef]

60. Hanson, P.; Edwards, N.; Garten, C.; Andrews, J. Separating root and soil microbial contributions to soil respiration: A review of methods and observations. Biogeochemistry 2000, 48, 115-146. [CrossRef]

61. Schlesinger, W.H.; Lichter, J. Limited carbon storage in soil and litter of experimental forest plots under increased atmospheric $\mathrm{CO}_{2}$. Nature 2001, 411, 466-469. [CrossRef] [PubMed]

62. Zhou, Z.; Zhang, Z.; Zha, T.; Luo, Z.; Zheng, J.; Sun, O. Predicting soil respiration using carbon stock in roots, litter and soil organic matter in forests of Loess Plateau in China. Soil Biol. Biochem. 2013, 57, 135-143. [CrossRef]

63. Chang, S.; Tseng, K.; Hsia, Y.; Wang, C.; Wu, J. Soil respiration in a subtropical montane cloud forest in taiwan. Agric. For. Meteorol. 2008, 148, 788-798. [CrossRef]

64. Raich, J.; Tufekciogul, A. Vegetation and soil respiration: Correlations and controls. Biogeochemistry 2000, 48, 71-90. [CrossRef]

65. Le Mer, J.; Roger, P. Production, oxidation, emission and consumption of methane by soils: A review. Eur. J. Soil Biol. 2001, 37, 25-50. [CrossRef]

66. Koehler, B.; Corre, M.; Steger, K.; Well, R.; Zehe, E.; Sueta, J.; Veldkamp, E. An in-depth look into a tropical lowland forest soil: Nitrogen-addition effects on the contents of $\mathrm{N}_{2} \mathrm{O}, \mathrm{CO}_{2}$ and $\mathrm{CH}_{4}$ and $\mathrm{N}_{2} \mathrm{O}$ isotopic signatures down to 2-m depth. Biogeochemistry 2012, 111, 695-713. [CrossRef]

67. Fender, A.; Pfeiffer, B.; Gansert, D.; Leuschner, C.; Daniel, R.; Jungkunst, H. The inhibiting effect of nitrate fertilisation on methane uptake of a temperate forest soil is influenced by labile carbon. Biol. Fertil. Soils 2012, 48, 621-631. [CrossRef]

68. Vanitchung, S.; Conrad, R.; Harvey, N.; Chidthaisong, A. Fluxes and production pathways of nitrous oxide in different types of tropical forest soils in Thailand. Soil Sci. Plant Nutr. 2011, 57, 650-658. [CrossRef]

69. Heil, J.; Liu, S.; Vereecken, H.; Brüggemann, N. Mechanisms of inorganic nitrous oxide production in soils during nitrification and their dependence on soil properties. In Proceedings of the EGU General Assembly, Vienna, Austria, 27 April-2 May 2014; p. 4208.

(C) 2016 by the authors; licensee MDPI, Basel, Switzerland. This article is an open access article distributed under the terms and conditions of the Creative Commons Attribution (CC-BY) license (http://creativecommons.org/licenses/by/4.0/). 